\title{
"Red Spitz Tumor" on the Ear: Case Report and Review of the Literature
}

\author{
YeHua Liang $\mathbb{D}^{\prime}$, Yijia Yu', Weimin Luan², Jinghong $\mathrm{Xu}{ }^{\prime}$ \\ 'Department of Plastic Surgery, The First Affiliated Hospital, School of Medicine, Zhejiang University, Hangzhou, Zhejiang, People's Republic of China; \\ ${ }^{2}$ Department of NeuroSurgery, Second Affiliated Hospital, School of Medicine, Zhejiang University, Hangzhou, Zhejiang, People's Republic of China \\ Correspondence: Jinghong Xu, Tel/Fax +86-57I-87236307, Email I3040I7@zju.edu.cn
}

\begin{abstract}
Spitz nevus (SN) is a benign melanocytic lesion with cytologic and architectural atypia. It is sometimes difficult to distinguish SNs from atypical Spitz tumor (AST), Spitz melanoma, or conventional melanoma. SNs frequently develop in Caucasians and appear on the skin of the head and lower extremities. Lesions on the ear in Asian populations are rare. Here, we report a "red Spitz tumor" on the ear of a Chinese 18year-old boy. Dermoscopic examination revealed possibly malignant features presented as polymorphous vessels along with central white area, pseudo-network depigmentation and atypical peripheral globular pattern. The results of histopathological examination strongly suggested that the neoplasm was a compound SN and no recurrences or metastases occurred during 1-year follow-up post-surgery. Further, we review the literature on 4 previously reported cases of $\mathrm{SN}$ on the ear and summarize the main points of SN diagnosis and differential diagnosis with atypical Spitz tumors and melanoma.
\end{abstract}

Keywords: Spitz nevus, atypical Spitz tumors, hypo-pigmented Spitz nevus, malignant melanoma

\section{Introduction}

Spitz nevi are melanocytic proliferations characterized by epithelioid or spindle melanocytes or both. Spitz proliferations may occur on a sequential biological spectrum ranging from benign Spitz nevi (SNs) to atypical Spitz tumors (ASTs) and malignant melanomas (MM), thus lead to a difficult differential diagnosis. Mis- or over-diagnosis elicits the variability in treatment recommendations. Given the poor overall survival rates of melanomas, an increased awareness and recognition for SNs is needed.

SNs are uncommon, and the overall estimated incidence ranges from 1.4 to 7 per 100,000 persons annually. Asian populations seem to be much less frequently influenced than Caucasians. SNs typically occur in children with no predilection for sex. Typical nevus lesions appear as symmetric, pink-red, smooth-surfaced, round, firm papule and can increase rapidly reaching a dimension of 6-8 $\mathrm{mm}$ at six months, then remain stationary for years. The commonly affected sites are located in the head and lower extremities. Special sites, such as the ear, appear rarely and raise a challenge with distinct features. ${ }^{1}$

In clinical, tan-black macules/plaques of pigmented SNs account for the large majority of excised SNs (79.5\%), while pink-red nodular SNs with a dotted/polymorphous vascular pattern are rare $(4.8 \%)^{2,3}$ The clinicopathologic definition "red Spitz tumors" raises as opposite to the "blue Spitz tumors". ${ }^{4}$ Dermoscopically, "red Spitz tumors" show pink-reddish color with a vascular pattern that predominates with dotted/polymorphous vessels. Histopathologically, they correspond to spindle and/or epithelioid cell neoplasms with little or no pigment and one or several features of atypia. These lesions sometimes disclose unspecific features, which are definitely worrisome.

Herein, we describe an uncommon case of Spitz nevus behaving as "red Spitz tumor" dermoscopically on the ear of a Chinese 18-year-old boy, and present a review of previously reported Spitz nevus cases on special sites gathered from the English-language literature. 


\section{Case Report}

A 18-year-old Chinese boy, who was otherwise healthy, presented to our Plastic Surgery clinic with a 1-year-history of an enlarging lesion on his antihelix of the left ear. The lesion appeared as a little red papule at the beginning and enlarged gradually without any discomfort. Family history of skin cancer and history of trauma was denied.

Physical examination revealed a $0.6 \mathrm{~cm} \times 0.6 \mathrm{~cm}$ well-circumscribed, relatively symmetric, dome-shaped, uniform reddish papule with a light verrucous surface (Figure 1A). Superficial telangiectasia and palpation of vascular pulsations on the surface were observed. No lymphadenopathy was found in his head or neck region. Laboratory examination revealed normal results of complete blood cell count and chemistry profile. No other abnormality was observed.

On dermatoscopic examination, a central white-red area was intermingled with polymorphous vessels including dotted, linear-irregular and comma-like features. A peripheral globular and pseudo-network pattern consisted of prominent brown pigmentation could be observed (Figure 1B). According to the seven-point checklist of dermoscopy and preference of the patient, excision was performed subsequently to clarify the pathological identity. ${ }^{5}$

The histopathological diagnosis was of a compound Spitz nevus, characterized by a symmetrical, well-circumscribed and sharply demarcated proliferation of nests or fascicles of melanocytes mainly located at the dermal-epidermal junction and within the superficial dermis (Figure 1C). Epidermis was hyperplastic, with pseudo-epitheliomatous hyperplasia (PEH). Central pagetoid scatter could be seen. Nests vertically oriented along rete as it was called "raining-down pattern". Melanocytic nests in epidermis were relatively uniform in size and shape, sharing the vertical orientation, and there were artifactual clefts between nests and adjacent keratinocytes. Nevus cells showed progressive maturation toward the base of the lesion and the melanin pigment was absent in the majority of the melanocytes except superficially (Figure 1D). A few Kamino bodies were noted (Figure 1E). Cytologically, the nests were composed of spindled cells and epithelioid cells (Figure 1F) with abundant amphophilic cytoplasm, prominent nuclei. Neither a significant number of mitoses nor individual cell necrosis was found.

As surgical resection margin was negative, no further immunohistochemistry examination was done. We have been following the patient closely post-surgery for 1 year, and no recurrence or metastasis was found.

\section{Discussion}

Although Allen and Spitz proposed a series of histologic criteria for Spitz's nevus in 1953, distinct variants include angiomatoid and desmoplastic SN, hyalinizing SN, polypoid SN and tubular SN have been described. Wide spectrum of morphologic appearance and varying degrees of vascularity make SNs sometimes difficult to be distinguished from hemangiomas, granulomas and malignant melanoma (MM) even today.

SNs are typified by starburst pattern (51\%), dotted vascular pattern $(19 \%)$ or globular pattern with reticular depigmentation $(17 \%)$ in dermoscopy. ${ }^{6}$ ASTs are dermoscopically typified by a multicomponent pattern and the morphology of melanoma usually follows the basic rule of asymmetry and multicomponent pattern. Histopathologic examination remains an imperfect gold standard for diagnosing Spitz proliferations. In a review of 349 Spitz nevi, the presence of epithelioid and spindled cells was the only feature in $100 \%$ of cases. Other findings included maturation (72\%), inflammatory infiltrate (70\%), epidermal hyperplasia (66\%), melanin (50\%), telangiectasias (40\%), Kamino bodies (34\%), desmoplastic stroma (26\%), mitosis (23\%), pagetoid extension (13\%), and hyalinization of the stroma $(8 \%){ }^{7}$ The points of differential diagnosis are listed in Table 1. Aside from AST and MM, the differential diagnosis includes Spark's nevus, which is a particular type of melanocytic nevus and used to be called "dysplastic Spitz". ${ }^{11}$ Clinically, it is more common in females and usually presents as an asymmetric, small size $(<1 \mathrm{~cm})$, pigmented lesion on the lower extremities. ${ }^{12,13}$ On histology, Spark's nevus shows the cytological features of Spitz's nevus (Spindle/ Epithelioid cells with evident central nucleolus and abundant cytoplasm) and the "bridging" architectural pattern of Clark's nevus. ${ }^{11}$ The parallel arrangement of melanocytes, lentiginous proliferation, bridging/confluence of nests, fibroplasia and lateral extension of the junctional give Spark's nevus the different characteristics from classic SN. ${ }^{13}$

In our case, the surgical margins were negative and histopathologic diagnosis was of a compound Spitz nevus. Ultimately, no further immunohistochemical and molecular analysis was done. However, in questionable cases, immunohistochemistry (IHC) and molecular analysis are recommended. Ki-67 (MIB-1), a proliferation marker, stains 

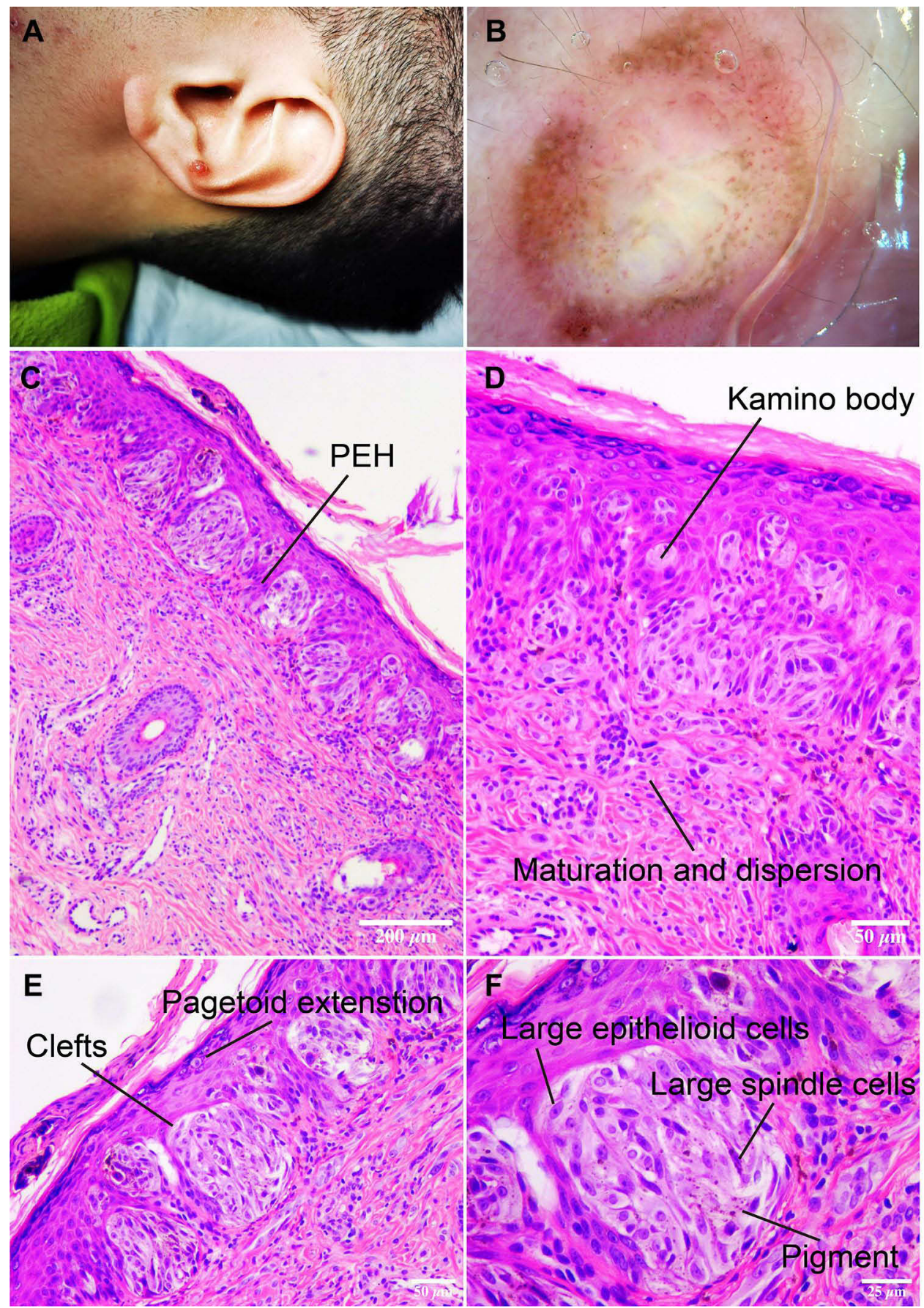

Figure I Appearance, dermatoscopic and histopathologic examination of the lesion. (A) Single, well-circumscribed $0.6 \times 0.6 \mathrm{~cm}$, dome-shaped, red papule on the left ear. (B) Dermatoscopic examination showed the central white-red area was intermingled with polymorphous vessels including dotted, linear-irregular and comma-like features. A peripheral globular and pseudo-network pattern consists of prominent brown pigmentation could be observed. (C) Epidermal hyperplasia with parakeratosis and pseudoepitheliomatous hyperplasia (PEH). A symmetric proliferation of variable-sized nests of melanocytes at the dermoepidermal junction with shrinkage artifacts around nests. Nests vertically oriented along rete, Melanocytes within the nests share the vertical orientation. (hematoxylin and eosin (H\&E) stain, scale bar $=200 \mu \mathrm{m}$ ). (D) Kamino body, rounded, dull pink areas of trapped basement membrane material within the epidermis. Nests diminish in size and show transition to single cells with depth. Diminished cellular and nuclear sizes with depth as called maturation. Melanocyte disperses at the base of the lesion. (hematoxylin and eosin (H\&E) stain, scale bar $=50 \mu \mathrm{m})$. (E) Clefts between melanocyte aggregates and adjacent keratinocytes. Central pagetoid scatter. The melanin pigment was absent in the majority of the melanocytes except superficially. (hematoxylin and eosin (H\&E) stain, scale bar $=50 \mu \mathrm{m})$. $(\mathbf{F})$ The nests are composed of spindled cells and epithelioid cells with abundant amphophilic cytoplasm, large but relatively uniform vesicular nuclei. Cellular shrinkage. Multinuclear cells were also noticed. No mitoses were found (hematoxylin and eosin (H\&E) stain, scale bar $=25 \mu \mathrm{m}$ ).

negatively/low level in SNs, whereas Ki-67-positive nuclei are numerous in melanoma. Vollmer, R.T. use Bayes rule to measure the proliferation index (PI) of the SN proliferations. Results estimate that PIs less than $2 \%$ favor an SN, more than $10 \%$ favor a melanoma, and $2 \%$ to $10 \%$ as indeterminate. ${ }^{14}$ HMB-45 is a melanogenesis-related protein and 
Table I Characteristics of Spitz Nevus, Atypical Spitzoid Tumors and Melanoma

\begin{tabular}{|c|c|c|c|}
\hline & Spitz Nevus (SN) & Atypical Spitzoid Tumors (AST) & Melanoma \\
\hline \multicolumn{4}{|l|}{ Architectural features } \\
\hline Clinical appearance & $\begin{array}{l}\text { Usually<6mm diameter } \\
\text { Symmetric }\end{array}$ & $\begin{array}{l}\text { Usually }>6 \mathrm{~mm} \text { diameter } \\
\text { Asymmetric }\end{array}$ & $\begin{array}{l}\text { Usually }>\text { I cm diameter } \\
\text { Often but not always asymmetric }\end{array}$ \\
\hline Epidermal reaction & $\begin{array}{l}\text { Hyperkeratosis } \\
\text { Pseudoepitheliomatous } \\
\text { hyperplasia } \\
\text { Minimal pagetoid spread }\end{array}$ & $\begin{array}{l}\text { Epidermis consumption } \\
\text { Prominent, single-cell Pagetoid spread, } \\
\text { beyond epidermal nests }\end{array}$ & $\begin{array}{l}\text { Minimal epidermal reaction } \\
\text { Obvious pagetoid spread into the } \\
\text { epidermis }\end{array}$ \\
\hline Melanocytic nests & $\begin{array}{l}\text { Ovoid nests of lesional cells } \\
\text { oriented perpendicular to the } \\
\text { epidermis } \\
\text { Uniform size and regular } \\
\text { spacing }\end{array}$ & $\begin{array}{l}\text { Lack zonation } \\
\text { Melanocytic nests and fascicles of } \\
\text { similar sizes within the deep dermis may } \\
\text { persistent }\end{array}$ & $\begin{array}{l}\text { Poorly nested } \\
\text { Nests variable in size, shape, and } \\
\text { orientation larger variable nests at } \\
\text { base }\end{array}$ \\
\hline Pigment & Little or no pigment & Variable & $\begin{array}{l}\text { Often heavily pigmented, or irregularly } \\
\text { scattered pigmented cells within the } \\
\text { lesion }\end{array}$ \\
\hline Kamino bodies & $\begin{array}{l}\text { Present in epidermis and } \\
\text { superficial dermis }\end{array}$ & Rare of absent & Absent \\
\hline Maturation & Maturation deep in the dermis & $\begin{array}{l}\text { Incomplete or absent dermal } \\
\text { maturation }\end{array}$ & Little or no maturation \\
\hline \multicolumn{4}{|l|}{ Cytological features } \\
\hline Cellular population & Uniform spindle/epithelioid cells & Epithelioid and/or spindle cells & Epithelioid and/or spindle cells \\
\hline Cytologic atypia & $\begin{array}{l}\text { Limited pleomorphism } \\
\text { Lack of high-grade cytologic } \\
\text { atypia }\end{array}$ & $\begin{array}{l}\text { Lack extreme pleomorphism } \\
\text { Increasing cytologic atypia }\end{array}$ & $\begin{array}{l}\text { Pleomorphism } \\
\text { High-grade cytological atypia }\end{array}$ \\
\hline Nucleoli & $\begin{array}{l}\text { Low nuclear-to-cytoplasmic } \\
\text { ratio } \\
\text { Open, delicate chromatin } \\
\text { patterns } \\
\text { Regular nuclear membranes } \\
\text { Uniform nucleoli }\end{array}$ & $\begin{array}{l}\text { Increasing high nuclear-to-cytoplasmic } \\
\text { ratio } \\
\text { Hyperchromatism } \\
\text { Thickening of nuclear membranes } \\
\text { Large nucleoli }\end{array}$ & $\begin{array}{l}\text { High nuclear-to-cytoplasmic ratio } \\
\text { Hyperchromatism } \\
\text { Irregular nuclear membranes } \\
\text { Large nucleoli }\end{array}$ \\
\hline $\begin{array}{l}\text { Mitotic rate } \\
\text { Dermoscopic features }\end{array}$ & $\begin{array}{l}\text { Few/no mitoses, }<2 / \mathrm{mm}^{2} \\
\text { No atypical mitoses }\end{array}$ & Frequent dermal mitosis, $2-6 / \mathrm{mm}^{2}$ & $\begin{array}{l}\text { Often high, } 2-6 / \mathrm{mm}^{2} \\
\text { atypical mitoses common }\end{array}$ \\
\hline Pigment & Little or no pigmentation & Homogeneous blue pigmentation & Atypical pigment network \\
\hline Vessels & Dotted vascular pattern & $\begin{array}{l}\text { Dotted or polymorphous vascular } \\
\text { pattern }\end{array}$ & Atypical vascular pattern \\
\hline Major pattern & $\begin{array}{l}\text { Starburst or peripheral globular } \\
\text { pattern }\end{array}$ & $\begin{array}{l}\text { Multicomponent pattern or a typical } \\
\text { nonpigmented Spitzoid pattern }\end{array}$ & $\begin{array}{l}\text { White-blue areas } \\
\text { Radial streaming (streaks) } \\
\text { Irregular blotches, dots and globules } \\
\text { Regression structures }\end{array}$ \\
\hline \multicolumn{4}{|l|}{$\begin{array}{l}\text { Immunohistochemical } \\
\text { Features }\end{array}$} \\
\hline & $\begin{array}{l}\text { Melan-A, pl6, SI00 positive } \\
\text { HMB- } 45 \text { decreases toward the } \\
\text { base } \mathrm{Ki}-67<2 \%\end{array}$ & $\begin{array}{l}\text { Melan-A, HMB-45, SI00 positive } \\
\text { Loss of pl6 } \\
\text { Ki-67 2\% 10\% }\end{array}$ & $\begin{array}{l}\text { Melan-A, HMB- } 45, \text { SI00 positive } \\
\text { loss of pl6 } \\
\text { Ki- } 67>10 \%\end{array}$ \\
\hline Molecular analysis & $\begin{array}{l}\text { HRAS, BAPI (+BRAF), TERTP } \\
\text { Kinase fusions: ALK, NTRKI, } \\
\text { NTRK3, ROSI, BRAF, RET, MET }\end{array}$ & $\begin{array}{l}\text { NRAS, HRAS, BRAF, BAPI } \\
\text { Kit fusions }\end{array}$ & $\begin{array}{l}\text { BRAF, NRAS, NFI, KRAS } \\
\text { Triple wild-type (eg KIT) } \\
\text { HRAS mutations rare }\end{array}$ \\
\hline
\end{tabular}

Note: Data from these studies ${ }^{8-10}$. 
Table 2 Summary of 4 Spitz Nevus/Atypical Spitz Tumor Arising on the Ear

\begin{tabular}{|c|c|c|c|c|c|c|c|}
\hline Author & Age/Sex & Location & $\begin{array}{l}\text { Time of } \\
\text { Evolution }\end{array}$ & Clinical Description & Diagnosis & Treatment & Follow-Up \\
\hline Wang L. et $\mathrm{al}^{16}$ & $10 \mathrm{y} / \mathrm{M}$ & Left helix & I year & $\begin{array}{l}\text { Multiple papules } \\
\text { arranged in a linear } \\
\text { Pink color and } \\
\text { prominent papillary } \\
\text { surface }\end{array}$ & Hypopigmented SN & Biopsy & $\begin{array}{c}3 \text { years/ } \\
\text { NRM }\end{array}$ \\
\hline Ferrara G. et al ${ }^{4}$ & $9 y / M$ & Right ear & - & $\begin{array}{l}\text { Multinodular polypoid } \\
\text { Prominent atypical } \\
\text { vascular pattern }\end{array}$ & Atypical Spitz tumor & Excision & - \\
\hline Mitsui Y. et al ${ }^{15}$ & $44 y / M$ & Right ear & I month & $\begin{array}{l}\text { Solitary red papule } \\
(6 \mathrm{~mm})\end{array}$ & Atypical Spitz tumor & Excision & - \\
\hline Busam KJ.et al ${ }^{17}$ & $21 \mathrm{y} / \mathrm{M}$ & $\begin{array}{l}\text { Right antihelix, } \\
\text { fifth toe, cheek }\end{array}$ & 9 years & $\begin{array}{l}\text { Dome-shaped pink } \\
\text { papules }(0.5 \mathrm{~cm})\end{array}$ & $\begin{array}{l}\text { Multiple combined } \\
B A P I^{\text {loss } / B R A F^{V 600 E}} \\
\text { melanocytic lesions }\end{array}$ & Excision & - \\
\hline Liang Y. et al & $18 \mathrm{y} / \mathrm{M}$ & Left antihelix & I year & $\begin{array}{l}\text { Dome-shaped, } \\
\text { uniform reddish } \\
\text { papule }(0.6 \mathrm{~cm} \times \\
0.6 \mathrm{~cm})\end{array}$ & $\begin{array}{l}\text { Compound Spitz } \\
\text { nevus }\end{array}$ & Excision & I year/ NRM \\
\hline
\end{tabular}

Abbreviations: SN, Spitz nevus; NRM, no recurrence or metastasis.

typically stains SNs in a top-heavy fashion, while melanomas stain uniformly top to bottom. P16, a cell cycle regulator, retains expression in most SNs, whereas it shows a loss in spitzoid melanomas and a minority of ASTs. S100A6, a subtype of S100, has also been proposed as a potential IHC marker, since it is expressed highly in SNs and diminished in malignant lesions. Molecular analysis has shown an increase in HRAS mutation in Spitz tumors specifically those with a copy number increase of chromosome 11p, which are absent in melanoma. Respectively, NRAS and BRAF mutations occur in approximately 20 and 70\% of melanomas but are not found in SNs (Table 1).

SNs rarely occur in the ears, anogenital region, breast and scalp. These areas are named as "Special sites". In our case, the neoplasm was localized on the left ear. On review of the English literature, there have been only 4 reported cases of SN in this region (Table 2). All of them showed hypo/no pigmentation and atypical dermoscopical pattern. Two cases were diagnosed as $\mathrm{ASTs},{ }^{4,15}$ one was hypopigmented $\mathrm{SN}$ and another case was multiple combined $B A P 1^{\text {loss }} / B R A F^{V 600 E}$ melanocytic lesions. ${ }^{16,17}$ Hypopigmented Spitz nevus is very rare in Chinese population. ${ }^{16}$ The lesion in our case was a uniform reddish papule, presenting central white area with polymorphous vascular pattern and pseudo-network depigmentation, suggesting the possibility of ASTs and called for an excision. Although the majority of ASTs exhibit a multicomponent pattern as mentioned before, whereas approximately $20 \%$ of them might dermoscopically mimic a nonpigmented SN, by accepting Urso's approach, ${ }^{18}$ atypical (possibly malignant) Spitzoid neoplasms are most often:

A. Large, commonly $>7 \mathrm{~mm}$ in diameter;

B. Nodular: more or less irregularly raised, palpable, firm, sometimes polypoid and/or ulcerated;

C. Hypo-amelanotic: pink-reddish in color, with a nondescript or, else, with a prominent and/or polymorphous vascular pattern.

The above listed features have been summarized in the clinicopathologic definition "red Spitz tumors", though sometimes unspecific dermoscopic features may be disclosed. ${ }^{4}$

There are several treatment options for Spitz nevi, including excision, electrosurgery and cryosurgery. The most advisable is complete excision as a precautionary measure especially in person at or beyond puberty. Clinical follow-up should be considered, for instance, annual or semi-annual evaluation may be recommended.

While the clinical and pathological features of the present case are described exhaustively, the representativeness of individual cases is limited. Further cases and research with large sample sizes are needed, given the lack of experience with this type of nevi and the small number of reported cases. 


\section{Conclusion}

In summary, we reported a case of "Special site" nevus presented on the ear with an alarming polymorphous vascular, peripheral globular, pseudo-network pattern and moderate pigmentation. Dermoscopic and histopathological findings of this uncommon skin lesion were provided, which can help both educationally and diagnostically in future cases. Awareness and recognition of classical and variable pattern of SNs are always the most important to avoid overdiagnosis as melanoma with all its associated implications.

\section{Acknowledgments}

This article has no funding source. We would like to express our great appreciation to the staff of the surgery laboratory of the First Affiliated Hospital, College of Medicine, Zhejiang University for their help and the patient who participated in this study.

\section{Disclosure}

The authors report no conflicts of interest in this work.

\section{References}

1. Vaccaro M, Marafioti I, Giuffrida R, Borgia F, Zalaudek I. Clinical and dermoscopic characterization of pediatric Spitz nevi of the ear. Pediatr Dermatol. 2021;38(4):895-898. doi:10.1111/pde.14616

2. Ferrara G, Argenziano G, Soyer HP, et al. The spectrum of Spitz nevi: a clinicopathologic study of 83 cases. Arch Dermatol. 2005;141 (11):1381-1387. doi:10.1001/archderm.141.11.1381

3. Ferrara G, Zalaudek I, Savarese I, Scalvenzi M, Argenziano G. Pediatric atypical spitzoid neoplasms: a review with emphasis on "red" (“spitz") tumors and "blue" ("blitz") tumors. Dermatology. 2010;220(4):306-310. doi:10.1159/000300093

4. Ferrara G, Cavicchini S, Corradin MT. Hypopigmented atypical Spitzoid neoplasms (atypical Spitz nevi, atypical Spitz tumors, Spitzoid melanoma): a clinicopathological update. Dermatol Pract Concept. 2015;5(1):45-52. doi:10.5826/dpc.050106

5. Argenziano G, Catricala C, Ardigo M, et al. Seven-point checklist of dermoscopy revisited. Br J Dermatol. 2011;164(4):785-790. doi:10.1111/ j.1365-2133.2010.10194.x

6. Lallas A, Apalla Z, Ioannides D, et al. Update on dermoscopy of Spitz/Reed naevi and management guidelines by the International Dermoscopy Society. Br J Dermatol. 2017;177(3):645-655. doi:10.1111/bjd.15339

7. Requena C, Requena L, Kutzner H, Sanchez Yus E. Spitz nevus: a clinicopathological study of 349 cases. Am J Dermatopathol. 2009;31 (2):107-116. doi:10.1097/DAD.0b013e3181934218

8. Cho-Vega JH. A diagnostic algorithm for atypical spitzoid tumors: guidelines for immunohistochemical and molecular assessment. Mod Pathol. 2016;29(7):656-670. doi:10.1038/modpathol.2016.70

9. Harms KL, Lowe L, Fullen DR, Harms PW. Atypical spitz tumors: a diagnostic challenge. Arch Pathol Lab Med. 2015;139(10):1263-1270. doi:10.5858/arpa.2015-0207-RA

10. Barnhill RL. The Spitzoid lesion: rethinking Spitz tumors, atypical variants, "Spitzoid melanoma" and risk assessment. Mod Pathol. 2006;19(Suppl 2):S21-S33. doi:10.1038/modpathol.3800519

11. Cimmino A, Cazzato G, Colagrande A, et al. Spitz nevus with features of Clark nevus, so-called SPARK nevus: case series presentation with emphasis on cytological and histological features. Dermatopathology. 2021;8(4):525-530. doi:10.3390/dermatopathology8040055

12. Toussaint S, Kamino H. Dysplastic changes in different types of melanocytic nevi. A unifying concept. J Cutan Pathol. 1999;26(2):84-90. doi:10.1111/j.1600-0560.1999.tb01807.x

13. Ko CJ, McNiff JM, Glusac EJ. Melanocytic nevi with features of Spitz nevi and Clark’s/dysplastic nevi (“Spark's” nevi). J Cutan Pathol. 2009;36 (10):1063-1068. doi:10.1111/j.1600-0560.2008.01221.x

14. Vollmer RT. Use of Bayes rule and MIB-1 proliferation index to discriminate Spitz nevus from malignant melanoma. Am J Clin Pathol. 2004;122 (4):499-505. doi:10.1309/MFFF-06D5-CYXR-2F8T

15. Mitsui Y, Ogawa K, Takeda M, Nakanishi T, Azukizawa H, Asada H. First Japanese case of atypical Spitz tumor exhibiting ROS1 rearrangement. J Dermatol. 2018;45(9):e248-e249. doi:10.1111/1346-8138.14293

16. Wang L, Wang G, Fan P, Gao T. Linear arrangement of hypopigmented Spitz nevi on the ear after trauma. J Dermatol. 2010;37(4):346-349. doi:10.1111/j.1346-8138.2010.00815.x

17. Busam KJ, Wanna M, Wiesner T. Multiple epithelioid Spitz nevi or tumors with loss of BAP1 expression: a clue to a hereditary tumor syndrome. JAMA Dermatol. 2013;149(3):335-339. doi:10.1001/jamadermatol.2013.1529

18. Urso C. A new perspective for spitz tumors? Am J Dermatopathol. 2005;27(4):364-366. doi:10.1097/01.dad.0000144261.92614.42 


\section{Publish your work in this journal}

Clinical, Cosmetic and Investigational Dermatology is an international, peer-reviewed, open access, online journal that focuses on the latest clinical and experimental research in all aspects of skin disease and cosmetic interventions. This journal is indexed on CAS. The manuscript management system is completely online and includes a very quick and fair peer-review system, which is all easy to use. Visit http://www. dovepress.com/testimonials.php to read real quotes from published authors.

Submit your manuscript here: https://www.dovepress.com/clinical-cosmetic-and-investigational-dermatology-journal 